\title{
Faktor demografis untuk meningkatkan informasi, edukasi, dan komunikasi kesehatan seksual dan reproduksi
}

\author{
Syauqy Lukman \\ Universitas Padjadjaran, Bandung, Indonesia
}

\begin{abstract}
ABSTRAK
Memahami siapa yang kurang berpengetahuan sangat penting dalam menentukan kebijakan yang berkaitan dengan aktivitas komunikasi, informasi, dan edukasi untuk meningkatkan pengetahuan kesehatan seksual dan reproduksi Remaja Indonesia. Penelitian ini mencoba untuk menegaskan kembali mengenai faktor-faktor demografis yang berhubungan dengan pengetahuan kesehatan seksual dan reproduksi remaja Indonesia. Penelitian ini menggunakan survei demografi dan kesehatan Indonesia (SDKI) tahun 2017, yang secara khusus melakukan survei kepada perempuan dan laki-laki belum menikah usia 15-24 tahun. Sampel survei diambil dari wawancara terhadap 48.963 rumah tangga, dengan rata-rata usia responden adalah 18,59 tahun. Dengan menggunakan analisis bivariat dan regresi, penelitian ini dapat menunjukkan bukti bahwa faktor usia, jenis kelamin, pendidikan, dan tempat tinggal memiliki asosiasi dengan pengetahuan kesehatan seksual dan reproduksi remaja Indonesia. Remaja perempuan yang belum menikah berusia 15-24 tahun, memiliki pengetahuan yang lebih baik dibandingkan laki-laki. Remaja dengan tingkat pendidikan yang lebih tinggi memiliki pengetahuan yang lebih baik dibandingkan dengan yang tingkat pendidikannya lebih rendah. Dengan bertambahnya usia responden, cenderung memiliki pengetahuan kesehatan dan seksual yang lebih baik. Terakhir, remaja yang tinggal di perkotaan cenderung lebih berpengetahuan dibandingkan dengan responden yang tinggal di pedesaan. Dengan demikian, sangat penting untuk menyempurnakan kebijakan dengan memberikan penekanan praktik komunikasi-informasi-edukasi kesehatan reproduksi dan seksual terhadap remaja laki-laki usia muda yang tinggal di pedesaan, dengan tingkat pendidikan yang lebih rendah, karena merekalah yang kurang memiliki pengetahuan kesehatan reproduksi seksual.
\end{abstract}

Kata-kata Kunci: Komunikasi kesehatan; demografi; kesehatan reproduksi seksual; SDKI; remaja

\section{Demographic factors for improving information, education and communication of sexual and reproductive health}

\begin{abstract}
Understanding who are the less knowledgeable is critical for policies related to information-educationcommunication (komunikasi, informasi, dan edukasi) of sexual and reproductive health knowledge of Indonesian Youth. This study tries to reaffirms past studies on four demographic factors that are associated with sexual and reproductive health knowledge of Indonesian youth, using the 2017 Demographic and Health Special Survey of Indonesia of never-married women and men aged 15-24. The survey samples from 48,963 households' interview, the average age of respondents were 18.59 years. Using bivariate analysis and regression, this study was able to determine that factors of age, gender, education, and residence are associated with sexual and reproductive health knowledge of Indonesian youth. Unmarried Indonesian women aged 15-24, are more knowledgeable compared to men. Young people with higher education level have better knowledge compared to people with lower education level. As young people get older, they will have better sexual and health knowledge. Lastly, young people living in urban area are also more knowledgeable compared to the rural counterpart. It is important to put more emphasis and improving policies on the practice of information-education-communication sexual and reproductive health towards younger men, living in the rural areas, with lower education level, as they are the less knowledgeable.
\end{abstract}

Keywords: Health communication; demography; sexual and reproductive health; SDKI; teenager

Korespondensi: Syauqy Lukman, S.Sos., M.S.M. Universitas Padjadjaran. Jl. Raya Bandung Sumedang KM.21, Hegarmanah, Kec. Jatinangor, Sumedang, Jawa Barat. 45363.Email: syauqy.lukman@unpad.ac.id

Submitted: March 2021, Accepted: May 2021, Published: June 2021

ISSN: 2303-2006 (print), ISSN: 2477-5606 (online). Website: http://jurnal.unpad.ac.id/jkk

Terakreditasi Kemenristekdikti RI SK No. 48a/E/KPT/2017 


\section{PENDAHULUAN}

Kondisi di Indonesia terkait pendidikan seks, berbeda dengan negara-negara barat yang mewajibkan muatan tersebut dalam sistem pendidikan formal. Pendidikan seks seringkali dianggap suatu hal yang kontroversial, terlebih bagi usia remaja. (Utomo \& Mcdonald, 2009). Secara budaya dan agama, masyarakat Indonesia meyakini bahwa hal-hal yang berhubungan dengan seks akan datang secara alamiah setelah menikah. Terlebih, sebagai negara dengan populasi Islam terbesar di dunia, penolakan terhadap pendidikan seks juga dirasakan pada masyarakat secara umum (Utomo \& Mcdonald, 2009).

Hanya beberapa penyelenggara pendidikan yang meluangkan sumber dayanya untuk pendidikan seks secara formal, kebanyakan adalah sekolah swasta. Kebijakan dari Kementerian Pendidikan dan Kebudayaan Indonesia terkait pendidikan seks, adalah dengan menyisipkan konten-konten tersebut pada mata pelajaran yang dianggap relevan seperti Biologi, Pendidikan Jasmani dan Kesehatan, Sosiologi, dan Pendidikan Agama (Utomo, McDonald, \& Hull, 2012). Badan Kependudukan dan Keluarga Berencana Nasional (BKKBN) adalah lembaga yang bertanggung jawab secara eksplisit atas pengetahuan kesehatan reproduksi seksual remaja, melalui program KIE, kependekan dari Komunikasi, Informasi dan Edukasi (Peraturan Pemerintah RI nomor 87/2014 tentang Perkembangan Kependudukan dan Pembangunan Keluarga, Keluarga Berencana, dan Sistem Informasi Keluarga, 2014).

Pengetahuan kesehatan reproduksi seksual, adalah variabel yang menentukan perilaku seksual manusia. Salah satu pemikir yang menjadi pionir mengenai pentingnya pengetahuan dalam mengurangi perilaku seksual berisiko adalah Douglas Kirby, dengan body of knowledge yang sangat ekstensif melalui argumennya bahwa pengetahuan akan menentukan perilaku seksual. Dari perspektif teoretis aspek kognitif berdasarkan social cognitive theory, social influence theory, social inoculations theory, cognitive behavioural theory, and the theory of reasoned action akan memengaruhi perilaku (Kirby \& Coyle, 1997. Namun peneliti yang sama juga berargumen bahwa pengetahuan kesehatan reproduksi seksual, mungkin juga tidak memiliki pengaruh langsung terhadap perubahan perilaku. Banyak proponen dari argumentasi bahwa pendidikan akan menentukan baik atau tidaknya pengetahuan kesehatan reproduksi seksual remaja (Kantor, Rolleri, \& Kolios, 2014; Kirby, 1985a; Utomo, 1997; Utomo, McDonald, Reimondos, Utomo, \& Hull, 2014).

Artikel ini mendukung pendapat bahwa pengetahuan kesehatan reproduksi seksual memiliki asosiasi dengan perilaku kesehatan reproduksi seksual yang aman. Berdasarkan hal tersebut, artikel ini akan mencoba melihat asosiasi antara pengetahuan kesehatan reproduksi seksual dengan beberapa faktor demografis utama, yaitu jenis kelamin, usia, pendidikan, dan lokasi tinggal pada responden usia remaja Indonesia. Artikel ini juga akan melihat apakah level pengetahuan kesehatan reproduksi seksual remaja dapat ditentukan oleh empat faktor demografis tersebut.

Pengetahuan kesehatan reproduksi seksual adalah sebuah variabel komposit yang digunakan untuk mengukur level pengetahuan beberapa komponen kunci topik dan isu kesehatan reproduksi seksual. Halhal yang seringkali ditanyakan atau diukur adalah pengetahuan terkait: siklus menstruasi dan proses pembuahan kehamilan, cara-cara menghindari kehamilan; metode kontrasepsi; cara penggunaan kondom dan alat kontrasepsi oral; pengetahuan mengenai penyakit menular seksual (PMS); HIV dan AIDS, penularan PMS dan cara menghindari penularannya, gejala PMS (Bertrand \& Kincaid, 1996; Figueroa, Kincaid, Rani, \& Lewis, 2002).

Sebuah body of knowledge atas kajian mengenai program-program pendidikan dan komunikasi pengetahuan kesehatan reproduksi seksual mengidentifikasi topik-topik penting yang harus disertakan dalam kajian-kajian kesehatan reproduksi seksual remaja di luar aspek pengetahuan. Topik-topik tersebut antara lain adalah: isu seputar keluarga berencana, kehamilan; HIV/AIDS dan PMS lainnya; kekerasan seksual; menstruasi dan higienitas perempuan; khitan laki-laki dan, mutilasi genitalia perempuan; hak-hak kesehatan reproduksi seksual; faktor-faktor yang memengaruhi kesehatan reproduksi seksual (Rankin, Heard, \& Diaz, 2016).

Kembali pada pemikiran-pemikiran Douglas Kirby, secara umum dapat disimpulkan bahwa komunikasi, informasi dan edukasi 
(KIE) kesehatan reproduksi seksual memiliki asosiasi positif dengan pengetahuan. Lebih lanjut, KIE sebagai anteseden dari pengetahuan, akan memengaruhi perilaku seksual (Kirby, 1985b; Kirby, Barth, Leland, \& Fetro, 1991; Kirby, Laris, \& Rolleri, 2007; Kirby et al., 1994; Kirby \& Coyle, 1997; Kirby \& Laris, 2009). Para proponen dari konsep ini meyakini bahwa dengan memberikan pengetahuan akan merubah sikap yang selanjutnya akan menghasilkan perubahan perilaku (Ingham \& Hirst, 2010; Parvanta \& Parvanta, 2011).

Dalam book chapter yang menjelaskan beberapa teori yang mengadopsi konsep-konsep Psikologi untuk menjelaskan bagaimana prilaku manusia dapat berubah sebagai hasil proses komunikasi kesehatan (Parvanta \& Parvanta, 2011), dijelaskan juga mengenai The Integrative Model of Behavioural Change, sebuah model yang dikembangkan dari theory of reasoned action and theory of planned behaviour (Fishbein \& Ajzen, 2010). Model ini dapat dilihat pada Gambar 1, dan dijelaskan bahwa pengetahuan (knowledge) adalah salah satu background factors dan berinteraksi dengan anteseden lain dalam menentukan perubahan perilaku (behavioural outcome) pada setting komunikasi kesehatan. Model inilah yang menjadi acuan landasan teoritis yang digunakan dalam melakukan analisis dalam studi ini.
Rendahnya pengetahuan kesehatan reproduksi seksual berasosiasi dengan sikap dan perilaku seksual yang berisiko (Salirawati, Ratna, \& Endarwati, 2014). Rendahnya pengetahuan kesehatan reproduksi seksual semakin memperburuk aktivitas seksual pranikah remaja, tanpa mempertimbangkan risiko PMS, termasuk HIV/AIDS dan kehamilan yang tidak diinginkan. (Utomo \& Mcdonald, 2008). Dalam studi yang lain, temuan menunjukkan bahwa rendahnya pengetahuan kesehatan reproduksi seksual berhubungan dengan prevalensi PMS, walaupun tidak menunjukkan bukti adanya asosiasi dengan perilaku seks berisiko (Needham, Wiemann, Tortolero, \& Chacko, 2010).

Dalam suatu studi literatur mengenai body of knowledge kajian-kajian program kesehatan reproduksi seksual remaja, pengetahuan diidentifikasi sebagai salah satu kategorioutcome atau variabel dependen, yang merupakan hasil dari program intervensi dan komunikasi kesehatan reproduksi seksual (Rankin et al., 2016). Dalam penelitian tersebut, intervensi yang dimaksud adalah: sistem kesehatan; akses finansial dan keamanan; pendidikan berbasis sekolah dan komunitas; sistem pendidikan yang mendukung, serta aspek pendukung dari komunitas, interpersonal, masyarakat, dan institusi.

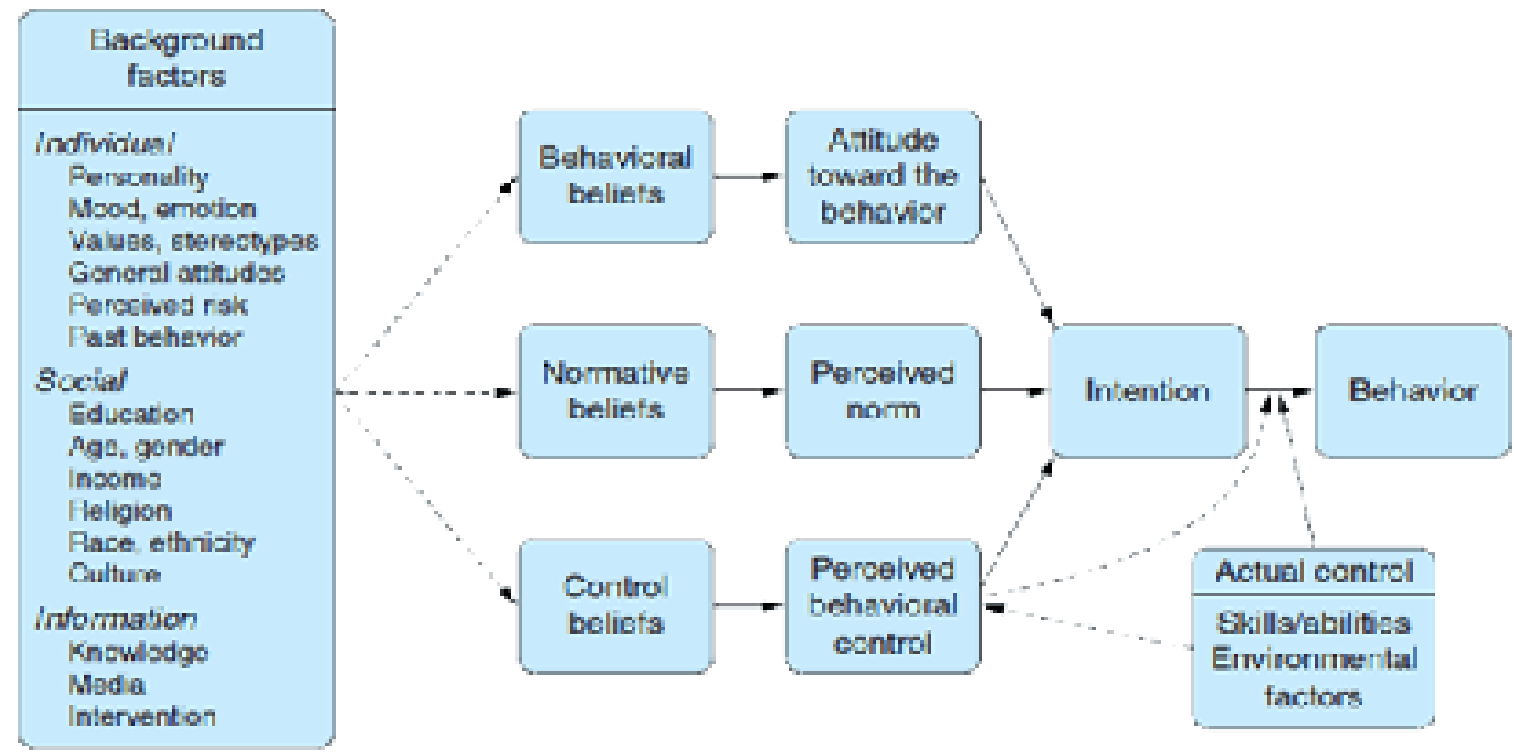

Sumber: Fishbein \& Ajzen, 2010

Gambar 1 The Integrative Model of Behavioural Change in Health Communication 
Dalam rangka melaksanakan KIE yang tepat sasaran, pemangku kebijakan harus memahami berbagai karakteristik dari target sasaran yang berbeda-beda, agar program KIE dapat diterima dengan baik. Sebuah studi mengenai kebutuhan informasi kesehatan reproduksi seksual pada pelajar tuna grahita di Bandung mendapati bahwa kelompok pelajar yang berkebutuhan khusus belum mendapatkan prioritas untuk diberikan intervensi berupa program KIE oleh para pemangku kebijakan. Kondisi pengetahuan kesehatan reproduksi seksual para remaja tunagrahita terbilang rendah, dan dari aspek perilaku mereka tidak menghindarkan diri dari perilaku seks berisiko (Setianti, Hafiar, Damayanti, \& Nugraha, 2019). Sebelum memberikan intervensi pada kelompok khusus, sangat penting untuk mengetahui kondisi demografis remaja-remaja yang kurang memiliki pengetahuan kesehatan reproduksi seksual secara umum. Hal tersebutlah yang berusaha dijawab oleh artikel ini.

Banyak kajian mengenai faktor-faktor yang memengaruhi pengetahuan kesehatan reproduksi seksual remaja. Dalam sebuah studi di tahun 2014, faktor-faktor demografis yang terdiri dari jenis kelamin, jenis sekolah, performa sekolah, provinsi, dan status sekolah, dapat digunakan untuk menjelaskan perbedaan remaja dalam memahami proses terjadinya kehamilan (Utomo et al., 2014). Dalam studi tersebut, responden laki-laki pelajar sekolah agama yang tinggal di pedesaan Indonesia Timur memiliki pemahaman yang rendah mengenai sexual intercourse dan proses terjadinya kehamilan. Menariknya, dalam sebuah studi yang sama pada situasi yang berbeda, tidak terdapat level pemahaman yang berbeda terkait pendidikan kesehatan seksual reproduksi berdasarkan perbedaan jenis kelamin, walaupun dalam penelitian tersebut, menunjukkan bahwa level pendidikan dapat menjelaskan level pengetahuan kesehatan reproduksi seksual.

Berdasarkan beberapa kajian terdahulu, sangat penting untuk menentukan hal-hal yang dapat memengaruhi pengetahuan, meskipun pengetahuan kesehatan reproduksi seringkali dioperasionalisasikan sebagai variabel determinan atau independen. Tujuan artikel ini adalah untuk mengetahui bagaimana faktorfaktor demografis akan memengaruhi level pengetahuan kesehatan reproduksi seksual remaja dalam konteks komunikasi dengan aspek yang diteliti adalah faktor-faktor demografis yang terdiri dari jenis kelamin, kelompok umur, pendidikan, dan lokasi tinggal (perkotaan/ pedesaan).

\section{METODE PENELITIAN}

Penelitian ini menguji asosiasi antara faktor demografis remaja Indonesia dengan level pengetahuan kesehatan reproduksi seksual. Selain itu penelitian ini juga mencari tahu bagaimana faktor demografis dapat memprediksi level pengetahuan menggunakan jenis kelamin, kelompok usia, pendidikan, dan lokasi tinggal (perkotaan/pedesaan).

Terdapat lima hipotesis yang hendak dibuktikan oleh penelitian ini: (1) terdapat efek signifikan dari jenis kelamin terhadap pengetahuan kesehatan reproduksi seksual remaja belum menikah di Indonesia; (2a) terdapat korelasi antara usia terhadap pengetahuan kesehatan reproduksi seksual; (2b) terdapat efek yang signifikan dari kelompok umur terhadap level pengetahuan kesehatan reproduksi seksual pada remaja belum menikah Indonesia; (3) terdapat pengaruh yang signifikan dari pendidikan terhadap skor pengetahuan kesehatan reproduksi seksual remaja belum menikah di Indonesia; (4) terdapat pengaruh yang signifikan dari lokasi tinggal (perkotaan/ pedesaan) terhadap pengetahuan remaja belum menikah di Indonesia; (5) faktor-faktor demografis jenis kelamin, usia, pendidikan, dan lokasi tinggal memiliki pengaruh signifikan terhadap pengetahuan kesehatan reproduksi seksual remaja.

Penelitian ini menggunakan data Survei Demografi dan Kesehatan Indonesia (SDKI) tahun 2017: Kesehatan Reproduksi Remaja (BKKBN, BPS, Kementerian Kesehatan RI, \& ICF International, 2017). Survei ini adalah survei potong-lintang yang dilakukan tiap lima tahun sekali sejak tahun 1987 oleh BKKBN, BPS, Kementerian Kesehatan, dengan pendanaan dari USAID. Survei khusus untuk usia remaja (15-24), baru dilakukan sejak tahun 2002-2003 dan penelitian ini mengambil item kuesioner pengetahuan mengenai pubertas, metode kontrasepsi, pengetahuan kesehatan reproduksi seksual, pengetahuan PMS dan HIV/AIDS sebagai komposit dari variabel 
pengetahuan yang utuh.

Survei ini adalah proyek nasional yang diselenggarakan pada seluruh provinsi di Indonesia (34 provinsi). Sampling dilakukan dengan metode sampling probabilitas tiga tahap, dengan memilih primary sampling unit (PSU) dengan pendekatan rumah tangga (household) secara PPS (probability proportional to size) dengan jumlah rumah tangga hasil sensus penduduk Indonesia pada 2010. Dari keseluruhan interview terhadap 48.963 rumah tangga, didapatkan sampel sebanyak 10.691 remaja laki-laki yang belum menikah dan 13.079 remaja perempuan yang disertakan dalam data set $(\mathrm{n}=23,770)$. Usia rata-rata responden adalah 18.59 tahun $(\mathrm{M}=$ $18.6, \mathrm{SD}=2.7)$. Survei dilakukan pada $24 \mathrm{Juli}$ 2017 hingga 30 September 2017, melibatkan 1.160 personel yang dilatih sebagai interviewer, supervisor, dan editor (BKKBN-National Population and Family Planning Board, BPSStatistics Indonesia, Ministry of HealthKementerian Kesehatan Republik Indonesia, \& ICF International, 2017).

Dalam penelitian ini, sebuah variabel komposit yang merupakan sebuah variabel numerik baru, dibuat berdasarkan variabelvariabel pertanyaan yang sesuai dengan konsep pengukuran pengetahuan kesehatan reproduksi seksual, merujuk pada "Illustrative questionnaire for interview-survey with young people" (Cleland, 2001). Development and Research Training in Human Reproduction (HRP) yang digunakan oleh HRP, program khusus terkait riset, pengembangan, dan pelatihan yang didanai oleh UNDP, UNFPA, WHO, dan World Bank. Kuesioner ini pulalah yang menjadi rujukan sejumlah Survei-survei kesehatan reproduksi seksual.

Variabel komposit pengetahuan kesehatan reproduksi seksual mengambil nilai nol atau satu, dari 39 variabel yang terdiri dari tujuh variabel yang mengukur pemahaman fisiologi reproduksi, 13 variabel mengukur pengetahuan metode kontrasepsi, 16 variabel mengukur pengetahuan seputar PMS dan HIV/AIDS, serta 3 variabel mengukur pengetahuan khusus tentang kondom. Nilai nol akan diberikan pada responden yang memberikan jawaban yang salah/tidak tahu atas satu pertanyaan, sementara nilai satu akan diberikan pada tiap jawaban yang benar/tahu.

$$
\text { Untuk kemudahan penyajian data }
$$

Tabel 1 Karakteristik Sampel berdasarkan Variabel Independen $(n=23,770)$

\begin{tabular}{lcc}
\hline \multicolumn{1}{c}{ Variabel } & Frekuensi & Presentase \\
\hline $\begin{array}{l}\text { Jenis Kelamin } \\
\text { Remaja belum } \\
\text { menikah laki-laki }\end{array}$ & 13,079 & 55.0 \\
Remaja belum & 10,691 & 45.0 \\
menikah & & \\
perempuan & & \\
Kelompok Usia & & \\
(mean = 18.59 & & \\
tahun) & & \\
15-19 & 15,191 & 64.0 \\
20-24 & 8,579 & 36.0 \\
Jenjang Pendidikan & & \\
Tertinggi & & \\
Sekolah Dasar & 1,582 & 6.7 \\
SMP & 3,260 & 13.8 \\
SMA & 14,027 & 59.3 \\
Akademi (Diploma & 805 & 3.4 \\
1, Diploma 2, & & \\
Diploma 3) & & \\
Diploma 4/ & 3,989 & 16.9 \\
universitas & & \\
Lokasi & & \\
Urban & 13,628 & 57.3 \\
Rural & 10,142 & \\
\hline
\end{tabular}

Sumber: Survei Demografi dan Kesehatan Indonesia (SDKI), 2017

deskriptif, umur tidak diperlakukan sebagai variabel kontinu, namun diubah menjadi variabel kategorikal berdasarkan dua kelompok umur yang lazim digunakan pada penelitian-penelitian sejenis dan merujuk pada pengelompokan yang digunakan SDKI, yaitu kelompok usia "15-19" dan kelompok usia "2024". Tabel 1 memberikan informasi deskriptif responden dalam sampel, berdasarkan pengelompokan variabel independen yang akan digunakan dalam untuk analisis statistik.

Seperti yang telah dijelaskan, variabel komposit pengetahuan kesehatan reproduksi seksual dibuat berdasarkan 39 variabel yang sebelumnya telah dijelaskan. Ringkasan statistiknya disajikan pada tabel 2 , yang terdiri dari item pertanyaan pengetahuan fisiologi reproduksi, pengetahuan metode kontrasepsi, 
Tabel 2 Ringkasan Statistik Pengetahuan Kesehatan Reproduksi Seksual $(n=23,770)$

\begin{tabular}{|l|c|c|c|}
\hline \multicolumn{1}{|c|}{ Variabel } & Mean & $\begin{array}{c}\text { Standar } \\
\text { Deviasi }\end{array}$ & $\begin{array}{c}\text { Nilai } \\
\text { Maksimum }\end{array}$ \\
\hline $\begin{array}{l}\text { Pengetahuan } \\
\text { Fisiologi } \\
\text { Reproduksi }\end{array}$ & 3.8 & 1.6 & 7 \\
\hline $\begin{array}{l}\text { Pengetahuan } \\
\text { Metode } \\
\text { Kontrasepsi }\end{array}$ & 4.3 & 2.6 & 13 \\
\hline $\begin{array}{l}\text { Pengetahuan } \\
\text { HIV/AIDS } \\
\text { dan PMS }\end{array}$ & 8.2 & 4.4 & 16 \\
\hline $\begin{array}{l}\text { Pengetahuan } \\
\text { Khusus } \\
\text { Pemakaian } \\
\text { Kondom }\end{array}$ & 2.1 & 1.0 & 3 \\
\hline $\begin{array}{l}\text { Skor } \\
\text { Komposit } \\
\text { Pengetahuan } \\
\text { Kesproseks }\end{array}$ & 18.5 & 7.9 & 39 \\
\hline
\end{tabular}

Sumber: Survei Demografi dan Kesehatan Indonesia (SDKI), 2017

pengetahuan PMS dan HIV/AIDS, dan pengetahuan khusus tentang kondom.

Setelah variabel komposit baru pengetahuan kesehatan reproduksi seksual dibuat, selanjutnya analisis dilakukan menggunakan analisis bivariat dan regresi berganda. Variabel dependen adalah skor pengetahuan kesehatan reproduksi seksual remaja belum menikah laki-laki dan perempuan usia 15-24, dengan variabel independen jenis kelamin, kelompok usia, pendidikan, dan lokasi tinggal (perkotaan/ pedesaan).

Analisis bivariat dengan t-test dilakukan pada variabel dikotomi jenis kelamin, kelompok umur, dan lokasi tinggal (perkotaan/pedesaan). Untuk variabel kategorikal pendidikan, analisis dilakukan dengan menggunakan $F$-test sementara analisis korelasional dilakukan pada variabel independen usia. Analisis regresi berganda dilakukan untuk menguji apakah variabel independen memiliki pengaruh yang secara statistik signifikan terhadap variabel dependen pengetahuan kesehatan reproduksi seksual. Semua pengujian dilakukan merujuk pada kaidah derajat kebebasan pada level signifikansi $\mathrm{p}<0.05$.

Regresi berganda atas variabel pengetahuan dilakukan menggunakan prediktor usia, variabel dummy jenis kelamin dengan perempuan sebagai kelompok referensi, lokasi tinggal dengan perkotaan sebagai referensi, dan pendidikan dengan pendidikan sekolah dasar sebagai referensi. Nilai adjusted $R$-squared dengan referensi derajat kebebasan pada level signifikansi $\mathrm{p}<0,05$ digunakan untuk menentukan apakah variabel independen secara signifikan memprediksi variabel dependen. Koefisien regresi dari model digunakan untuk membuat persamaan regresi studi yang dapat digunakan untuk membuat model yang memprediksi variabel dependen.

\section{HASIL DAN PEMBAHASAN}

Tahap analisis pertama adalah melakukan $t$-test pengetahuan kesehatan reproduksi seksual berdasarkan jenis kelamin, usia, dan lokasi tinggal. Pada tabel 3, tersaji hasil pengujian statistik nilai mean dari pengetahuan kesehatan reproduksi seksual dengan menggunakan $t$-test. Hasilnya, terdapat efek signifikan dari jenis kelamin, usia, dan lokasi tinggal (perkotaan/ pedesaan) pada remaja belum menikah terhadap pengetahuan mereka. Nilai skor rerata pengetahuan remaja perempuan lebih tinggi sebanyak 2,79 poin dibandingkan remaja lakilaki $\left(\mathrm{t}_{23768}=27.04, \mathrm{p}<0.05\right)$, di mana nilai mean untuk pengetahuan perempuan adalah 20.04 berbanding 17.25 untuk laki-laki. Responden yang lebih tua pada kelompok usia 20-24 tahun, memiliki skor lebih tinggi dibandingkan responden yang lebih muda, 15-19 $\left(\mathrm{t}_{23768}=\right.$ $37.94, \quad \mathrm{p}<0.05)$ dengan nilai rerata skor responden usia 15-19 adalah 17.08 berbanding rerata responden $20-24$ pada 21.02 . Responden di daerah perkotaan memiliki rerata skor 3.18 poin lebih tinggi dibandingkan responden yang tinggal di pedesaan $\left(\mathrm{t}_{20651}=-30.84, \mathrm{p}<0.05\right)$ dengan nilai rerata 19.86 untuk responden perkotaan, berbanding 16.68 pada responden di pedesaan.

Analisis bivariat selanjutnya adalah uji korelasional antara variabel kontinu usia dengan pengetahuan. Setelah melalui perhitungan statistik dapat disimpulkan bahwa hubungannya dapat diabaikan dengan koefiesien korelasional 
Tabel 3 Nilai Mean Pengetahuan Kesehatan Reproduksi Seksual Remaja di Indonesia tahun 2017 berdasarkan jenis kelamin, usia, dan lokasi (pengujian t-test)

\begin{tabular}{lccc}
\hline \multicolumn{1}{c}{ Variabel Kategori Dikotomis } & Obeservasi & Mean & Standar Deviasi \\
\hline Jenis Kelamin $(\mathrm{t}=27.40)$ & & & \\
Remaja Perempuan & 10,691 & 20.04 & 7.88 \\
Remaja Laki-Laki & 13,079 & 17.25 & 7.71 \\
Total (perbedaan=2.79) & 23,770 & 18.50 & 7.91 \\
Age $(\mathrm{t}=-37.94)$ & & & \\
$15-19$ & 15,191 & 17.08 & 0.061 \\
$20-24$ & 8,579 & 21.02 & 0.084 \\
Total $($ perbedaan $=-3.93)$ & 23,770 & 18.50 & 0.051 \\
Residence $(\mathrm{t}=30.84, \mathrm{df}=20651)$ & & & \\
Urban & 13,628 & 19.86 & 0.063 \\
Rural & 10,142 & 16.68 & 0.081 \\
Total $($ perbedaan $=3.18)$ & 23,770 & 18.50 & 0.051 \\
\hline
\end{tabular}

Catatan:perbedaan nilaireratapengetahuan kesehatan reproduksiseksual, signifikansecara statistic pada $p<0.05$ dengan df (derajat kebebasan) $=n-2$, dengan perkecualian pada variable lokasi tinggal di mana variansnya berbeda, pengujian dilakukan dengan t-test for unequal variances $d f=20651$

Sumber: Survei Demografi dan Kesehatan Indonesia (SDKI), 2017

$=0,08\left(\mathrm{r}_{23768}=0.29, \mathrm{p}<0.05\right)$ mengindikasikan hanya $8 \%$ variansi dari pengetahuan dapat dijelaskan dengan perbedaan rentang usia.

Berikutnya pengujian statistik bivariat yang dilakukan adalah melakukan $F$-test pengetahuan berdasarkan variabel kategorikal pendidikan. Perlu diketahui bahwa pada variabel ini, yang didefinisikan dengan pendidikan adalah jenjang pendidikan tertinggi yang pernah ditempuh oleh responden, terlepas dari responden lulus jenjang tersebut atau tidak. Sejatinya ada variabel 'tidak pernah sekolah' sebanyak 300 responden, yang mana dari 300 responden tersebut sempat menempuh Pendidikan sekolah dasar. Tabel 4 berikut, menyajikan informasi hasil $F$-test yang dimaksud.

Terdapat pengaruh yang signifikan atas level pengetahuan Kesehatan reproduksi seksual remaja belum menikah, berdasarkan pendidikan tertinggi $\mathrm{F}_{4,23663}=2034.19, \mathrm{p}<$ 0.05 dengan nilai mean pengetahuan adalah $9.72(\mathrm{SD}=7.25), 13.43(\mathrm{SD}=7.61), 18.74$ $(\mathrm{SD}=6.73), 26.69(\mathrm{SD}=6.64)$, dan 23.89 $(\mathrm{SD}=6.10)$ berturut-turut untuk sekolah dasar, sekolah menengah pertama, sekolah menengah atas, akademi dan diploma, serta D4/ universitas. Namun, perlu diperhatikan bahwa sampel responden dengan jenjang Pendidikan diploma jumlahnya lebih sedikit dibandingkan sampel Pendidikan universitas, dengan mean nilai pengetahuan yang lebih tinggi pula. Secara logis, hal ini adalah sebuah kesalahan karena variabel ordinal Pendidikan seharusnya dapat memprediksi nilai pengetahuan secara linier berdasarkan semakin tingginya jenjang pendidikan. Hal ini akan dijawab untuk pada bagian analisis menggunakan regresi berganda.

Setelah analisis bivariat, tahap selanjutnya adalah analisis regresi berganda menggunakan semua variabel independen terhadap variabel dependen. Jumlah observasi yang disertakan dalam perhitungan regresi adalah 23.663, tanpa menyertakan missing data. Asumsi linearitas dilanggar pada model regresi pertama, saat variabel ordinal pendidikan tidak memprediksi pengetahuan secara linier. Hal ini terjadi karena jumlah observasi kelompok akademi/D1/D2/D3 yang sedikit $(\mathrm{n}=805)$. Solusi yang dipilih adalah dengan melakukan pengelompokan ulang, di mana kelompok kategori ini dimasukkan ke 
Tabel 4 Nilai rerata pengetahuan Kesehatan reproduksi remaja belum menikah di Indonesia berdasarkan pendidikan yang ditempuh

\begin{tabular}{lccc}
\hline $\begin{array}{l}\text { J e n j a n g } \\
\text { Pendidikan }\end{array}$ & Frekuensi & Mean & $\begin{array}{c}\text { Standar } \\
\text { Deviasi }\end{array}$ \\
\hline $\begin{array}{l}\text { Sekolah } \\
\text { Dasar }\end{array}$ & 1,582 & 9.72 & 7.25 \\
$\begin{array}{l}\text { Sekolah } \\
\text { Menengah }\end{array}$ & 3,260 & 13.43 & 7.61 \\
$\begin{array}{l}\text { Pertama } \\
\text { Sekolah }\end{array}$ & 14,027 & 18.74 & 6.73 \\
$\begin{array}{l}\text { Menengah } \\
\text { Atas }\end{array}$ & & & \\
$\begin{array}{l}\text { Akademi/D1/ } \\
\text { D2/D3 }\end{array}$ & 805 & 26.69 & 6.64 \\
$\begin{array}{l}\text { D4/ } \\
\text { universitas }\end{array}$ & 3,989 & 23.89 & 6.10 \\
Total & $23,663 *$ & 18.54 & 7.88 \\
\hline
\end{tabular}

Catatan: f-test secara statistik signifikan F4, $23660=2034.19, p<0.05$, *missing data tidak disertakan dalam perhitungan

Sumber: Survei Demografi dan Kesehatan Indonesia (SDKI), 2017

dalam kelompok yang sama dengan responden pendidikan D3/universitas, sehingga variabel pendidikan hanya terdiri dari empat kelompok dari sebelumnya lima.

Setelah menggunakan pengujian variance inflation factors (vif), model regresi tidak menunjukkan adanya multikolinearitas. Terdapat sejumlah observasi dengan nilai residual ter standarisasi lebih besar dari 2,5, yang menunjukkan beberapa variabel yang perlu mendapatkan perhatian. Uji jarak Cook (Cook's distance) tidak menemukan pencilan dengan nilai ' $d$ ' lebih besar dari 1, menunjukkan tidak adanya pencilan. Tidak ada pengamatan dengan kekuatan leverage lebih dari 0,5 , hal ini menunjukkan tidak ada pengamatan dengan masalah leverage terhadap koefisien regresi.

Residual dari model regresi terdistribusi secara normal setelah memerhatikan histogram. Plot standardized normal probability plot dan quintile-normal plot juga tidak menunjukkan gejala non-normalitas pada nilai-nilai pertengahan dan nilai ekstrem, meskipun pengujian normalitas Shapiro-Wilk menunjukkan residual tidak terdistribusikan secaranormal pada $<<0.05$. Plotresidual terhadap fitted model dan hasil pengujian Breusch-Pagan menunjukkan bahwa residual tidak homogen. Solusi dari kondisi heterokedastisitas ini adalah dengan menggunakan regresi berganda dengan robust standardized error. Hasil dari regresi linier tersebut dapat dilihat pada tabel 5.

Tabel 5 Hasil analisis regresi linier berganda pengetahuan kesehatan seksual dan reproduksi pada remaja laki-laki dan perempuan belum menikah di Indonesia (total $\mathrm{n}=23,663$; adj $\mathrm{R2}=0,30$ ) dengan robust standard error (model 2$)$

\begin{tabular}{lll}
\hline $\begin{array}{l}\text { Pengetahuan Kesehatan } \\
\text { Reporduksi Seksual (mean } \\
\text { score }=18.54, \text { max }=39)\end{array}$ & & \\
\hline & $\beta$ & SE \\
Usia (15-24) & 0.59 & 0.018 \\
$\begin{array}{l}\text { Jenis Kelamin (referensi: } \\
\text { remaja perempuan) }\end{array}$ & & \\
$\begin{array}{l}\text { Remaja laki-laki } \\
\text { Pendidikan tertinggi } \\
\text { (referensi: sekolah dasar) }\end{array}$ & -1.82 & 0.088 \\
& & \\
$\begin{array}{l}\text { Sekolah Menengah Pertama } \\
\text { Sekolah Menengah Atas }\end{array}$ & 4.33 & $*$ \\
& 8.96 & $*$ \\
& 12.4 & 0.186 \\
Akademi, Diploma, dan & 1 & 0.207 \\
$\begin{array}{l}\text { Universitas } \\
\text { Lokasi Tinggal (referensi: } \\
\text { perkotaan) }\end{array}$ & & \\
& & 0.089 \\
& -1.58 & $*$ \\
kons (p<0.040) & 0.77 & 0.375 \\
\hline
\end{tabular}

Catatan: Nilai standard error yang diberikan bintang menunjukkan perubahan nilai antara model pertama dengan model kedua, dengan pembulatan angka pada tiga desimal. Seluruh variabel independen secara statistik signifikan pada pada $p<0.05$; F6, 23656.

Sumber: Survei Demografi dan Kesehatan Indonesia (SDKI) tahun 2017: Kesehatan Reproduksi Remaja 
Persamaan regresi untuk penelitian ini dengan standard error robust adalah:

Prediksi skor pengetahuan kesehatan reproduksi seksual $=0,59-1,82$ (remaja lakilaki) $+4,33$ (Sekolah Menengah Pertama) $+8,96$ (Sekolah Menengah Atas) $+12,41$ (akademi, diploma, universitas - 1,58 (pedesaan). Nilai koefisien determinasi regresi adjusted $R^{2}$ adalah sebesar 0,30 menunjukkan proporsi varians variabel dependen yang ditentukan oleh variabel independen sebanyak $30 \%$ dan $70 \%$ varians variabel dependen pengetahuan kesehatan reproduksi seksual ditentukan oleh variabel lain di luar persamaan regresi pada tabel 5 .

Nilai intercept persamaan regresi untuk skor pengetahuan kesehatan reproduksi seksual adalah 0,77 poin. Koefisien untuk variabel usia adalah sebesar 0,59 poin, dengan penambahan usia pada responden menghasilkan peningkatan pengetahuan kesehatan reproduksi seksual sebesar 0,59 poin. Koefisien untuk variabel remaja laki-laki adalah negatif 1,82 poin di mana remaja laki-laki belum menikah diprediksi akan mendapat skor 1,82 lebih rendah dibandingkan remaja perempuan. Nilai koefisien untuk variabel jenjang pendidikan tertinggi adalah 4,33 poin untuk responden berpendidikan Sekolah Menengah Pertama, 8,96 poin untuk sekolah menengah atas, dan 12,41 poin untuk responden dengan pendidikan akademi, diploma atau universitas, menggunakan kategori sekolah dasar sebagai referensi.

Responden diperkirakan secara berturutturut akan memperoleh skor pengetahuan kesehatan reproduksi seksual sebanyak 4,33, 8,96 , dan 12,41 poin lebih tinggi masingmasing berdasarkan pencapaian pendidikan tertinggi sekolah menengah pertama, sekolah menengah atas, dan akademi/diploma/ universitas. Koefisien untuk variabel lokasi tinggal adalah negatif 1,58 poin untuk pedesaan, yang memprediksi responden yang tinggal di pedesaan akan mendapat skor pengetahuan kesehatan reproduksi seksual 1,58 poin lebih rendah dibandingkan dengan responden yang tinggal di daerah perkotaan.

Pada tabel 6, disajikan prediksi margin berdasarkan model regresi berganda, tanpa menyertakan variabel kontinu usia. Variabel kontinu usia ditransformasi menjadi variabel dikotomi yang membagi usia 15-19 tahun dan 20-24 tahun berdasarkan pengelompokan pada survei. Tabel tersebut menunjukkan bahwa
Tabel 6 Prediksi margin pengetahuan seksual dan kesehatan reproduksi pada pria dan wanita belum menikah di Indonesia (total $\mathrm{n}=23.663$, nilai maks $=39$ )

\begin{tabular}{|c|c|c|}
\hline Variabel & Margin & Standar Error \\
\hline Usia & & \\
\hline $15-19$ & 17.62 & 0.055 \\
\hline $20-24$ & 20.18 & 0.075 \\
\hline $\begin{array}{l}\text { Jenis } \\
\text { Kelamin }\end{array}$ & & \\
\hline $\begin{array}{l}\text { Remaja Laki- } \\
\text { laki }\end{array}$ & 19.55 & 0.064 \\
\hline $\begin{array}{l}\text { Remaja } \\
\text { Perempuan } \\
\text { Education } \\
\text { attainment }\end{array}$ & 17.72 & 0.058 \\
\hline $\begin{array}{l}\text { Sekolah } \\
\text { Dasar }\end{array}$ & 10.12 & 0.167 \\
\hline $\begin{array}{l}\text { Sekolah } \\
\text { Menengah } \\
\text { Pertama }\end{array}$ & 14.45 & 0.118 \\
\hline $\begin{array}{l}\text { Sekolah } \\
\text { Menengah } \\
\text { Atas }\end{array}$ & 19.08 & 0.056 \\
\hline $\begin{array}{l}\text { Academi/ } \\
\text { diploma/ } \\
\text { universitas }\end{array}$ & 22.53 & 0.105 \\
\hline $\begin{array}{l}\text { Lokasi } \\
\text { Tinggal }\end{array}$ & & \\
\hline Perkotaan & 19.22 & 0.057 \\
\hline Pedesaan & 17.64 & 0.066 \\
\hline
\end{tabular}

Catatan: semua margin prediksi signifikan pada $p<0,05$

Sumber: Survei Demografi dan Kesehatan Indonesia (SDKI), 2017

remaja perempuan diprediksi memiliki skor pengetahuan yang lebih tinggi dibandingkan remaja laki-laki. Prediksi selanjutnya adalah semakin tinggi jenjang pendidikan, maka semakin tinggi prediksi skor pengetahuan kesehatan reproduksi seksual responden. Terakhir, responden yang tinggal di perkotaan diprediksi memiliki skor yang lebih tinggi dibandingkan di pedesaan. 
Berdasarkan prediksi margin persamaan regresi, remaja perempuan memperoleh skor pengetahuan kesehatan reproduksi seksual 2,79 poin lebih tinggi dibandingkan remaja lakilaki dengan nilai rata-rata remaja putri 19,95 dan remaja putra 17,72 poin. Meskipun ada studi yang menyatakan bahwa tidak terdapat perbedaan atas pemahaman tentang pendidikan seks (setara dengan pengetahuan kesehatan seksual dan reproduksi) berdasarkan dari jenis kelamin, (Salirawati et al., 2014; Utomo et al., 2014)Salirawati et al., 2014; Utomo et al., 2014 berpendapat bahwa remaja perempuan memiliki pemahaman yang lebih baik tentang hubungan seksual dan konsepsi (juga setara dengan pengetahuan kesehatan seksual dan reproduksi). Penelitian ini menegaskan bahwa jenis kelamin adalah prediktor yang memengaruhi variabel independen pengetahuan kesehatan reproduksi seksual.

Untuk memperkuat argumentasi bahwa jenis kelamin adalah salah satu faktor penentu level pengetahuan kesehatan reproduksi seksual, maka diperlukan perspektif sejarah kebijakan keluarga berencana di Indonesia. Dalam buku yang berjudul "Masyarakat, Kependudukan, dan Kebijakan di Indonesia", kita dapat merefleksikan bahwa secara historis pemerintah Indonesia, bahkan sebelum kemerdekaan (Pemerintah Hindia Belanda) memberikan intervensi perencanaan keluarga secara khusus kepada perempuan (Hull, Hull, Utomo, \& Adioetomo, 2005). Fokus pada kebijakan keluarga berencana pada perempuan juga terlihat dalam Survei Demografi dan Kesehatan Indonesia (SDKI), yang menggunakan data set tahun 2017 untuk penelitian ini. Tidak ada kuesioner untuk pria dalam survei 1987, 1991, 1994, dan 1997. Kuesioner untuk laki-laki baru tersedia sejak SDKI tahun 2002/2003.

Semakin tua usia responden maka akan diperoleh nilai pengetahuan kesehatan seksual yang semakin tinggi pula. Responden pada kelompok umur 20-24 memperoleh nilai 2.56 poin lebih tinggi dari pada responden yang lebih muda umur 15-19 tahun dengan rata-rata nilai responden umur 15-19 tahun sebesar 17,62 dan rata-rata nilai responden umur 20-24 tahun sebesar 20,18 (berdasarkan predicted margin persamaan regresi berganda). Secara logis ini masuk akal, karena kita manusia seharusnya akan lebih banyak pengetahuan seiring bertambahnya usia.
Responden di perkotaan memperoleh skor yang lebih tinggi dibandingkan dengan responden di perdesaan dengan skor rata-rata responden yang tinggal di perkotaan sebesar 19,22 dan skor rata-rata masyarakat perdesaan sebesar 17,64 (berdasarkan predicted margin persamaan regresi berganda). Hal ini sesuai dengan temuan beberapa penelitian yang juga menunjukkan adanya pengaruh faktor lokasi tinggal terhadap level pengetahuan kesehatan reproduksi seksual (Salirawati et al., 2014; Utomo et al., 2014).

Terdapat pengaruh yang signifikan dari tingkat pendidikan tertinggi remaja belum menikah terhadap skor pengetahuan kesehatan reproduksi seksual. Skor pengetahuan tersebut akan meningkat seiring dengan semakin tingginya level. Bukti ini konsisten dengan penelitian terdahulu yang mendukung anggapan bahwa responden dengan tingkat pendidikan yang lebih tinggi akan memiliki pengetahuan kesehatan yang lebih baik dalam berbagai kategori (Parvanta \& Parvanta, 2011)

Interaksi jenis kelamin, umur, tingkat pendidikan, dan tempat tinggal memiliki hubungan yang signifikan dengan pengetahuan kesehatan seksual dan reproduksi. Secara statistik pengetahuan kesehatan seksual dan reproduksi remaja belum menikah di Indonesia juga dapat diprediksi dengan menggunakan penyebut jenis kelamin, usia, tingkat pendidikan, dan tempat tinggal.

Studi ini menegaskan dan mengkonfirmasi beberapa asumsi mengenai tingkat pengetahuan kesehatan reproduksi seksual yang dipengaruhi oleh aspek demografis jenis kelamin (jenis kelamin), usia, pencapaian pendidikan, dan tempat tinggal (pedesaan/perkotaan) yang juga banyak dimunculkan pada penelitian-penelitian terdahulu. Terdapat pengaruh yang signifikan secara statistik pada jenis kelamin, usia, dan tempat tinggal remaja belum menikah terhadap nilai pengetahuan kesehatan reproduksi seksual berdasarkan survei demografi dan kesehatan Indonesia tahun 2017.

Meskipun studi ini berhasil mengkonfirmasikan asumsi penelitian terdahulu bahwa pengetahuan kesehatan seksual dan reproduksi dapat diprediksi oleh faktor demografis jenis kelamin, usia, pencapaian pendidikan, dan tempat tinggal, harus diakui hal ini adalah bukan sesuatu yang baru. Meskipun demikian, kontribusi makalah ini terletak pada 
penggunaan indeks gabungan Pengetahuan kesehatan reproduksi seksual yang digunakan juga pemanfaatan data set SDKI 2017 yang memiliki jumlah sampel yang representatif untuk mewakili populasi remaja belum menikah di Indonesia. Variabel kesehatan reproduksi seksual dibangun berdasarkan "illustrative questionnaire for interview-survey with young people"(Cleland et al., 2001)Development and Research Training in Human Reproduction (HRP, dengan mempertimbangkan 39 variabel tentang topik fisiologi reproduksi, metode kontrasepsi, HIV/AIDS dan PMS lainnya, serta pengetahuan khusus tentang penggunaan kondom.

Lazimnya pengetahuan diukur dengan metode yang hanya mengandalkan kebenaran jawaban, menafsirkan jawaban yang benar atau salah untuk mencerminkan bahwa seseorang tahu atau tidak tahu sesuatu. Metode pengukuran seperti ini tentunya akan memiliki kekurangan yang dapat diperbaiki dengan memperluas definisi pengetahuan untuk memasukkan kepastian hasil pengujian (Hunt, 2003). Lebih lanjut, Hunt mengasumsikan dengan memasukkan respons penilaian diri "yakin" dan "tidak yakin" untuk memberikan perkiraan yang wajar tentang kepastian orang tersebut dalam mengetahui jawaban yang tepat untuk sebuah pertanyaan akan menciptakan pengukuran pengetahuan yang lebih baik. Jawaban yang benar dengan pilihan "tidak yakin" akan dinilai lebih rendah dibandingkan dengan jawaban yang benar ditanggapi dengan pasti ("yakin"). Sayangnya, karena penelitian ini menganalisis data SDKI 2017 yang tidak memasukkan parameter kepastian responden dalam memberikan jawaban, maka simplifikasi penilaian pengetahuan harus dikompromikan dengan membuat skor sederhana 0 dan 1 sesuai jawaban salah dan benar.

\section{SIMPULAN}

Dibuatnya variabel komposit pengetahuan kesehatan reproduksi seksual dapat dilihat sebagai sebuah penyederhanaan yang berlebihan dalam upaya untuk mengukur kondisi riil level pengetahuan tersebut. Terlebih karena metode pengukuran skor komposit, mengabaikan jawaban terbuka yang berasal dari responden yang memberikan lebih dari satu jawaban. Variabel gabungan ini juga mengabaikan jawaban "saya tidak tahu" dari pertanyaan ya dan tidak. Untuk mendeskripsikan pengetahuan secara akurat, responden yang menjawab pertanyaan dengan jawaban "Saya tidak tahu" seharusnya perlu diperlakukan dengan hatihati dalam analisis, karena respons tersebut juga dapat mencerminkan apakah responden tidak memahami pertanyaan, tidak mengetahui jawaban suatu pertanyaan, atau mungkin hanya malas dalam menanggapi pertanyaan tersebut.

Dengan mengabaikan argumen apakah skor komposit pengetahuan kesehatan reproduksi seksual dapat secara akurat dan valid mencerminkan pengetahuan riil dari responden atas aspek-aspek kesehatan reproduksi dan seksual, nilai rata-rata yang diperoleh dari skor komposit adalah sebesar 18,54. Nilai ini relatif rendah jika dibandingkan dengan nilai maksimum 39. Hal ini menunjukkan dua isu penting dengan catatan yang perlu mendapatkan perhatian.

Gagasan pertama adalah, skor gabungan yang diperoleh diyakini merupakan cerminan dari kondisi aktual pengetahuan kesehatan reproduksi seksual remaja Indonesia usia 1524. Angka ini tergolong rendah karena kurang dari 20 poin dari nilai maksimum 39 . Hal ini memunculkan pertanyaan: "apakah benar remaja di Indonesia kurang pengetahuan kesehatan reproduksi seksualnya?

Untuk gagasan yang kedua, ada kemungkinan bahwa skor komposit tidak mengukur dengan benar pengetahuan kesehatan reproduksi seksual, sehingga perlu pendekatan berbeda dalam menentukan level pengetahuan kesehatan reproduksi seksual remaja. Melihat kembali Tabel 2, terdapat kemungkinan redundansi dalam menyusun skor untuk pengetahuan tentang metode kontrasepsi dan pengetahuan tentang HIV/AIDS dan IMS karena banyaknya item pertanyaan untuk dua komponen ini yaitu, masing-masing sebanyak 13 dan 16 pertanyaan. Kita juga perlu mempertimbangkan adanya variabel lain yang tidak termasuk dalam data dalam survei, yang dapat dikategorikan ke dalam building block yang membangun pengetahuan kesehatan reproduksi seksual. Berdasarkan argumen tersebut, diperlukan pengembangan lebih lanjut dalam menentukan variabel yang tepat untuk mengukur pengetahuan kesehatan reproduksi 
seksual untuk studi-studi selanjutnya.

Berdasarkan regresi berganda pengetahuan kesehatan reproduksi seksual yang diprediksi oleh variabel independen, dapat kita simpulkan bahwa kombinasi terbaik karakteristik remaja belum menikah di Indonesia yang memiliki pengetahuan kesehatan reproduksi seksual yang baik adalah remaja perempuan pada kelompok usia 20-24, dengan jenjang pendidikan akademi/ diploma/universitas dan tinggal di daerah perkotaan. Hal ini menunjukkan ketimpangan level pengetahuan berdasarkan pendidikan dan lokasi tinggal, dan perlu menjadi perhatian bagi pemangku kebijakan dalam menentukan arah kebijakan komunikasi-informasi-edukasi kesehatan reproduksi seksual.

Rendahnya pengetahuan remaja laki-laki, menunjukkan bahwa perhatian lebih perlu diberikan kepada komunikasi-informasiedukasi remaja laki-laki. Secara historis, program-program KIE, memang lebih dititikberatkan untuk perempuan yang sudah menikah. Hasil studi ini menunjukkan bahwa perlu adanya program yang memfokuskan pada intervensi terhadap remaja laki-laki.

\section{DAFTAR PUSTAKA}

Bertrand, J. T., \& Kincaid, D. L. (1996). Evaluating information-educationcommunication (iec) programs for family planning and reproductive health. Carolina Population Center, University of North Carolina at Chapel Hill.

BKKBN-National Population and Family Planning Board, BPS-Statistics Indonesia, Ministry of Health-Kementerian Kesehatan Republik Indonesia, \& ICF International. (2017). Indonesian Demographic and Health Survey 2017: Adolescents Reproductive Health. Jakarta, Indonesia: BKKBN, BPS, Kemenkes, and Rockville, Maryland, USA: ICF.

BKKBN, BPS, Kementerian Kesehatan RI, \& ICF International. (2017). Survei demografi dan kesehatan: kesehatan reproduksi remaja 2017. survei demografi dan kesehatan Indonesia 2017. Jakarta, Indonesia: BKKBN, BPS, Kemenkes, and Rockville, Maryland, USA: ICF.

Cleland, J., Ingham, R., \& Stone, N. (2001).
Asking young people about sexual and reproductive health behaviours: illustrative core instruments. hrp - special programme of research, development and research training in human reprodcution. UNDP, UNFPA, WHO, World Bank.

Figueroa, M. E., Kincaid, D. L., Rani, M., \& Lewis, G. (2002). Communication for social change: an integrated model for measuring the process and its outcomes (The Communication for Social Change Working Paper Series No. 1). https://doi. org/10.1097/00006454-198804000-00003

Fishbein, M., \& Ajzen, I. (2010). Predicting and changing behaviour: the reasoned action approach. New York: Psychology Press, taylor \& francis Group.

Hull, T. H., Hull, V. J., Utomo, I. D., \& Adioetomo, S. M. (2005). Peope, population, and policy in Indonesia. (Terrence H. Hull, Ed.). Jakarta: Equinox Publishing - Ford Foundation.

Hunt, D. P. (2003). The concept of knowledge and how to measure it. Journal of Intellectual Capital, 4(1), 100-113. https:// doi.org/10.1108/14691930310455414

Ingham, R., \& Hirst, J. (2010). Promoting sexual health. In P. Aggleton, C. Dennison, \& I. Warwick (Eds.), Promoting health and wellbeing through schools (pp. 1-177). New York: Routledge.

Kantor, L. M., Rolleri, L., \& Kolios, K. (2014). Doug Kirby's contribution to the field of sex education. Sex Education, 14(5). https://doi.org/10.1080/14681811.2014.88 1336

Kirby, D. (1985a). Sexuality education: a more realistic view of its effects. Journal of School Health, 55(10), 421-424. https://doi.org/10.1111/j.1746-1561.1985. tb01169.x

Kirby, D. (1985b). The effects of selected sexuality education programs: Toward a more realistic view. Journal of Sex Education and Therapy, 11(1), 28-37. https://doi.org/10.1080/01614576.1985.11 074819

Kirby, D., Barth, R. P., Leland, N., \& Fetro, J. V. (1991). Reducing the risk: Impact of a new curriculum on sexual risk-taking. Family Planning Perspectives, 23(6), 253-263. https://doi.org/10.2307/2135776 
Kirby, D., \& Coyle, K. (1997). School-based programs to reduce sexual risk-taking behavior. Children and Youth Services Review, 19(5-6), 415-436. https://doi. org/10.1016/S0190-7409(97)00025-X

Kirby, D., \& Laris, B. A. (2009). Effective curriculum-based sex and STD/HIV education programs for adolescents. Child Development Perspectives, 3(1), 21-29. https://doi.org/10.1111/j.17508606.2008.00071.x

Kirby, D., Laris, B. A., \& Rolleri, L. A. (2007). Sex and hiv education programs: their impact on sexual behaviors of young people throughout the world. Journal of Adolescent Health, 40(3), 206-217. https:// doi.org/10.1016/j.jadohealth.2006.11.143

Kirby, D., Short, L., Collins, J., Rugg, D., Kolbe, L., Howard, M., ... Zabin, L. S. (1994). School-based programs to reduce sexual risk behaviors: A review of effectiveness. Public Health Reports, 109(3), 339-360.

Needham, H. E., Wiemann, C. M., Tortolero, S. R., \& Chacko, M. R. (2010). Relationship between health literacy, reading comprehension, and risk for sexually transmitted infections in young women. Journal of Adolescent Health, 46(5), 506-508. https://doi.org/10.1016/j. jadohealth.2009.11.195

Parvanta, S. A., \& Parvanta, C. (2011). Persuasive health communications: the role of theory. In C. Parvanta, D. E. Nelson, S. A. Parvanta, \& R. N. Harner (Eds.), Essentials of Public Health Communication (pp. 145-158). Sudburry, MA: Jones \& Bartlett Learning, LLC.

Peraturan Pemerintah RI nomor 87/2014 tentang perkembangan kependudukan dan pembangunan keluarga, keluarga berencana, dan sistem informasi keluarga (2014). Indonesia.

Putri, N. E., Hakim, N., \& Yamin, M. (2016). Ecologicall footprint and biocapacity analysis for flooding prevention in South Sumatera. Jurnal Mimbar, 32(1), 58-64.
Retrieved from https://ejournal.unisba. ac.id/index.php/mimbar/article/view/1729/ pdf

Rankin, K., Heard, A., \& Diaz, N. (2016). Adolescent sexual and reproductive health: the state of evidence on the impact of programming in low-and middle-income countries (3ie Scoping Paper No. 5).

Salirawati, D., Ratna, K., \& Endarwati, M. L. (2014). Survey terhadap pemahaman pendidikan seks dan sikap/perilaku seks di kalangan remaja di Daerah Istimewa Yogyakarta. Jurnal Penelitian Humaniora, 19(1), 85-95.

Setianti, Y., Hafiar, H., Damayanti, T., \& Nugraha, A. R. (2019). Media informasi kesehatan reproduksi bagi remaja disabilitas tunagrahita di Jawa Barat. Jurnal Kajian Komunikasi, 7(2), 170. https://doi. org/10.24198/jkk.v7i2.22655

Utomo, I. D. (1997). Sexual attitudes and behaviour of middle-class young people in Jakarta. The Australian National University.

Utomo, I. D., \& Mcdonald, P. (2008). Religion , media, westernisation and sexuality among young people in urban middle class Indonesia. Intersections: Gender and Sexuality in Asia and the Pacific, (18).

Utomo, I. D., \& Mcdonald, P. (2009). Adolescent reproductive health in indonesia : contested values and policy inaction. Studies in Family Planning, 40(2), 133-146.

Utomo, I. D., McDonald, P., \& Hull, T. H. (2012). Gender and reproductive health study improving reproductive health education in the indonesian national curriculum. Canberra.

Utomo, I. D., McDonald, P., Reimondos, A., Utomo, A., \& Hull, T. H. (2014). Do primary students understand how pregnancy can occur? A comparison of students in Jakarta, West Java, West Nusa Tenggara and South Sulawesi, Indonesia. Sex Education, 14(1), 95-109. https://doi.org/10.1080/14681811. 2013.833503 